\title{
The influence of environmental factors on the supranivean activity of flies (Diptera) in Central Poland
}

\author{
AgNIESZKA SOSZYŃSKA \\ Department of Invertebrate Zoology and Hydrobiology, University of Lodz, ul. Banacha 12/16, 90-237 Lodz, Poland; \\ e-mail: agasosz@biol.uni.lodz.pl
}

Key words. Snow activity, atmospheric factors, phenology, Diptera, Poland

\begin{abstract}
More than half of the insects collected on snow in Central Poland were flies (Diptera). Altogether 83 species of Diptera from 27 families were identified, of which 9 families were recorded for the first time. Two thirds of the Diptera belonged to the Mycetophilidae and Trichoceridae, which were also very species-rich. Other families with many species were the Heleomyzidae, Sphaeroceridae and Phoridae.

The peak activity was in the first part of December. Flies were most active on snow when the humidity ranged from 80 to $100 \%$, temperatures between -1 to $5^{\circ} \mathrm{C}$ and the snow was from 20 to $40 \mathrm{~cm}$ deep. The occurrence of Trichoceridae was strictly associated with high humidities, in contrast to Drosophilidae and Heleomyzidae, which were most active at lower humidities. The activity of the flies of the most frequently recorded families was displaced towards either lower (Heleomyzidae and Limoniidae) or higher temperatures (Trichoceridae, Mycetophilidae). In contrast to other families, the supranivean activity of Phoridae was strictly associated with thin snow cover.
\end{abstract}

\section{INTRODUCTION}

Snow forms an ecotone between a cold and unstable environment and warmer and more stable conditions under the snow. Snow cover of about $20 \mathrm{~cm}$, defined as the "hiemal threshold", insulates soil and the subnivean space from fluctuations in air temperature (Aitchison, 1979a). This enables several invertebrates to remain active below the snow and appear on the snow surface when temperatures are favourable to feed, copulate or migrate.

Snow provides winter-active invertebrates with three different microhabitats: beneath (subnivean), in (intranivean) and on the snow (supranivean). These microhabitats are interconnected and organisms may move between them in order to find the optimal conditions. For that reason the faunas of these microhabitats are changeable and hard to define.

Animals occurring on the surface of snow are commonly called the "snow fauna". This fauna is poorly known. A great diversity of invertebrates, however, occur on the surface of snow (Aitchison, 2001), such as rotifers, nematodes (Starmach et al., 1976), terrestrial crustaceans, oligochaetes, snails (Aitchison, 1979e), mites (Aitchison, 1979c), spiders (Huhta \& Viramo, 1979; Ashmole et al., 1983; Koponen, 1989), especially of the families Erigonidae and Linyphiidae (Łęgowski \& Łoziński, 1995), phalangids, pseudoscorpions (Aitchison, 1979f) and a great diversity of insects - springtails (Aitchison, 1979a; Brummer-Korvenkontio M. \& Brummer-Korvenkontio L., 1980; Aitchison, 1983; Hågvar, 2000), caddis-flies (Szczęsny, 1968; Sowa \& Szczęsny, 1970), stoneflies, cockroaches, homopterans (Aitchison, 1978a), heteropterans (Frey, 1913), scorpion-flies (Strübing, 1958; Shorthouse, 1979; Courtin at al., 1984; Viramo, 1989;
Hågvar, 2001), beetles (Aitchison, 1979b), flies (Aitchison, 1979d; Hågvar \& Greve, 2003), Hymenoptera (Szulczewski, 1947; Aitchison, 1979d) and geometrid moths (Błeszyński, 1960).

Although the winter activity of Diptera is a common phenomenon and certain flies are active at low temperatures, it is rarely studied. Many species are active during the entire winter, particularly on and beneath the snow. The most common flies recorded on snow are from the following families: Trichoceridae, Mycetophilidae, Chironomidae, Phoridae, Sphaeroceridae, Heleomyzidae, Drosophilidae, Anthomyiidae and to some extent Simuliidae, Stratiomyidae, Muscidae, Scatophagidae, Ephydridae, Lauxanidae, Sciomyzidae, Agromyzidae, Lonchopteridae, Dolichopodidae as well as Cecidomyidae (Aitchison, 2001; Hågvar \& Greve, in press), Anisopodidae (Hancock, 1991) and Chloropidae (Vaněk, 1973). In most cases, data on their snow-activity come from rather outdated studies on psychrofilic insects or invertebrates as a whole (Frey, 1913; Tahvonen, 1942; Aitchison, 1979d, 2001). The winter activity of species of many dipteran families was investigated by Broen \& Mohring (1964), and of only the suborder Brachycera by Bährmann (1996). Some of the best studied, in terms of snow-activity, are the: Limoniidae (Marchand, 1917; Hågvar, 1971, 1976; Krzemiński, 1978), Chironomidae (Hågvar \& Ostbye, 1973, Jonsson \& Sandlund, 1975), Mycetophilidae (Plassmann, 1975, 1989, Kjærandsen, 1993), all Brachycera (Hågvar \& Greve, 2003) and Phoridae (Soszyńska \& Durska, 2002).

Additional data on the winter activity of Diptera are provided by studies using pitfall traps (soil and litter) and yellow trays (Renken, 1956; Aitchison, 1979d, 2001; Łęgowski \& Łoziński, 1995; Buck, 1997). 


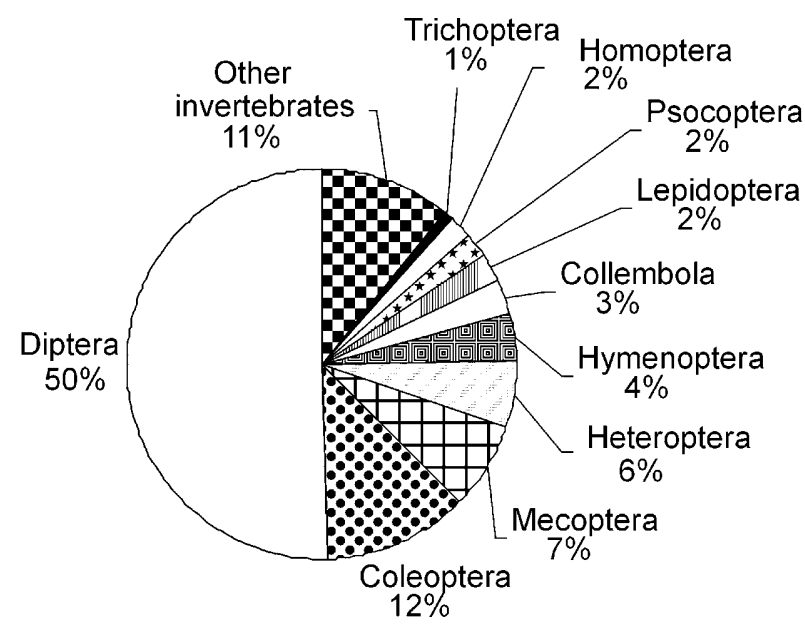

Fig. 1. Percentages of the different invertebrate groups collected from the surface of snow, based on individuals.

The aim of this paper is to provide a list of the common species and families of supranivean-active Diptera and record the temperature and humidity conditions, and depth of snow when they are active.

\section{MATERIAL AND METHODS}

\section{Study area}

The investigation was carried out in an area designed in the

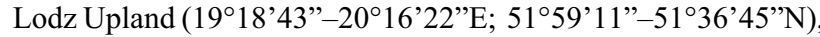
according to the physicogeographical division of Europe (Kondracki, 2000). The area is located in Central Poland, in the vicinity of one of the biggest cities of Poland - Lodz. Lodz Upland is unusual as it is the northernmost upland peninsula in Poland, surrounded by lowlands and characterized by a unique landscape; it experiences the lowest temperatures, highest air humidities and the longest period of snow-cover in Central Poland. The highest point in this area - the escarpment belt, is $284 \mathrm{~m}$ a. s. 1.

The peculiarities of this region are determined by features common to both uplands and lowlands, interesting landscape, clean rivers, remains of natural forest, very old trees in primeval forests and a unique and rich flora and fauna. For this reason, the Lodz Upland Landscape Park was founded to protect this area (Kurowski, 1998).

Supranivean-active invertebrates were sampled in natural forests in nature reserves and the largest forest areas. Thus was done in several forest associations: mixed forests including old

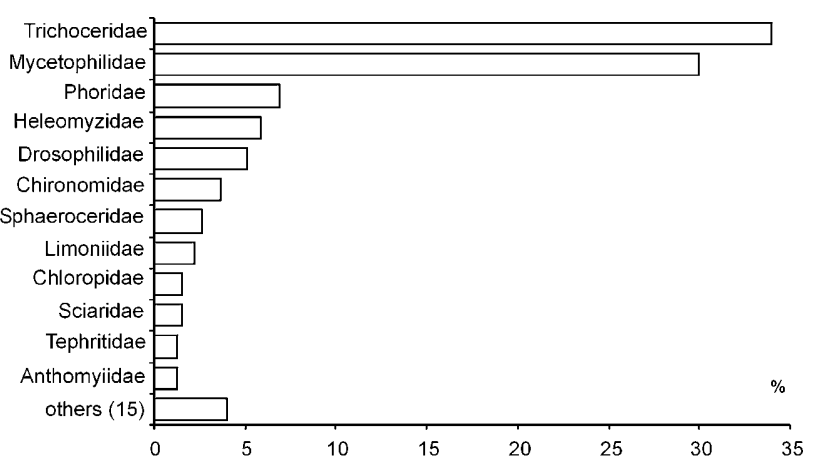

Fig. 2. Percentages of certain families of Diptera, based on individuals.

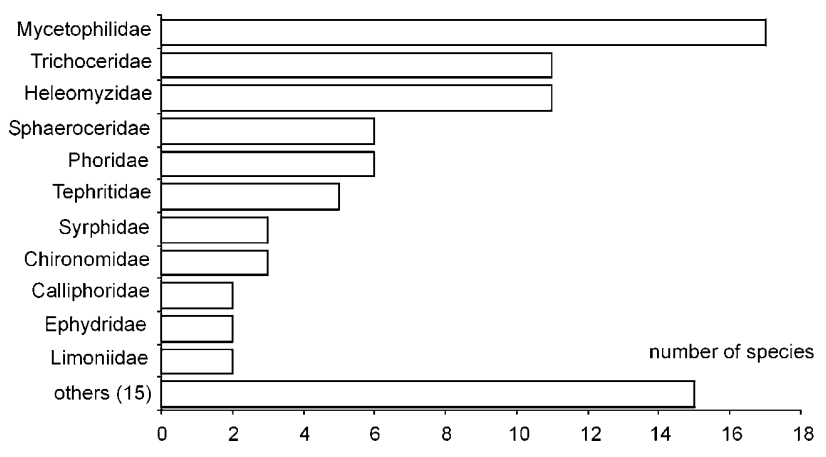

Fig. 3. Numbers of species of all the snow-active families of Diptera.

beeches, spruces and firs, riparian forests (Circeo-Alnetum) in the vicinity of springs, acidophilous beech woods (Luzulo pilosae-Fagetum) including 100-years old beeches, in dry, flatbottomed valleys, dry-ground forests (Tilio-Carpinetum) and forests overgrowing banks of natural, unregulated rivers.

\section{Insects and methods}

Altogether 3863 invertebrates were collected of which 2022 were flies.

Invertebrates were sampled using a semi-quantitative method. They were collected over a period of $1.5 \mathrm{~h}$ at each location, from November to March, at temperatures ranging from -10 to $+10^{\circ} \mathrm{C}$ in four winters, $1998-2002$. The collections were made, if possible, every day there was snow cover.

Seasons of the year were defined according to Kłysik (2001) for Central Poland. Autumn is defined as October, early winter as November until mid-December, winter as the period between mid-December and beginning of March, early spring as March and spring as April.

Air temperature, humidity and the depth of the snow were noted at each sampling location. The air temperature and humidity was measured $1 \mathrm{~m}$ above the snow surface in the shade using a thermo-hygrometer AZ 8721. Temperature and humidity close to the surface may have deviated a little from this.

\section{RESULTS}

Half of the winter-active specimens were flies (Diptera) (Fig. 1). Therefore, flies became the main subject of this investigation. Apart from Diptera, the most numerous

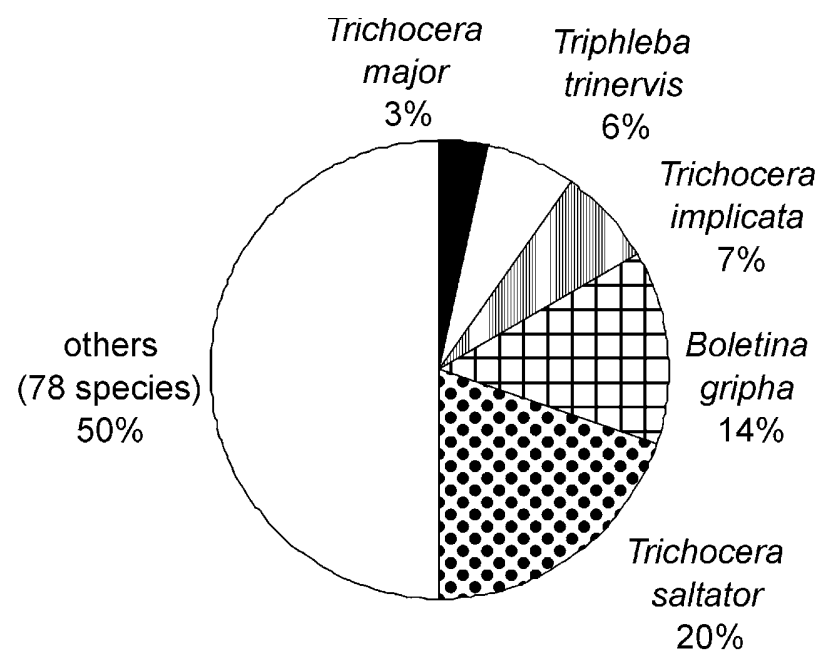

Fig. 4. Percentages of the most abundant species. 

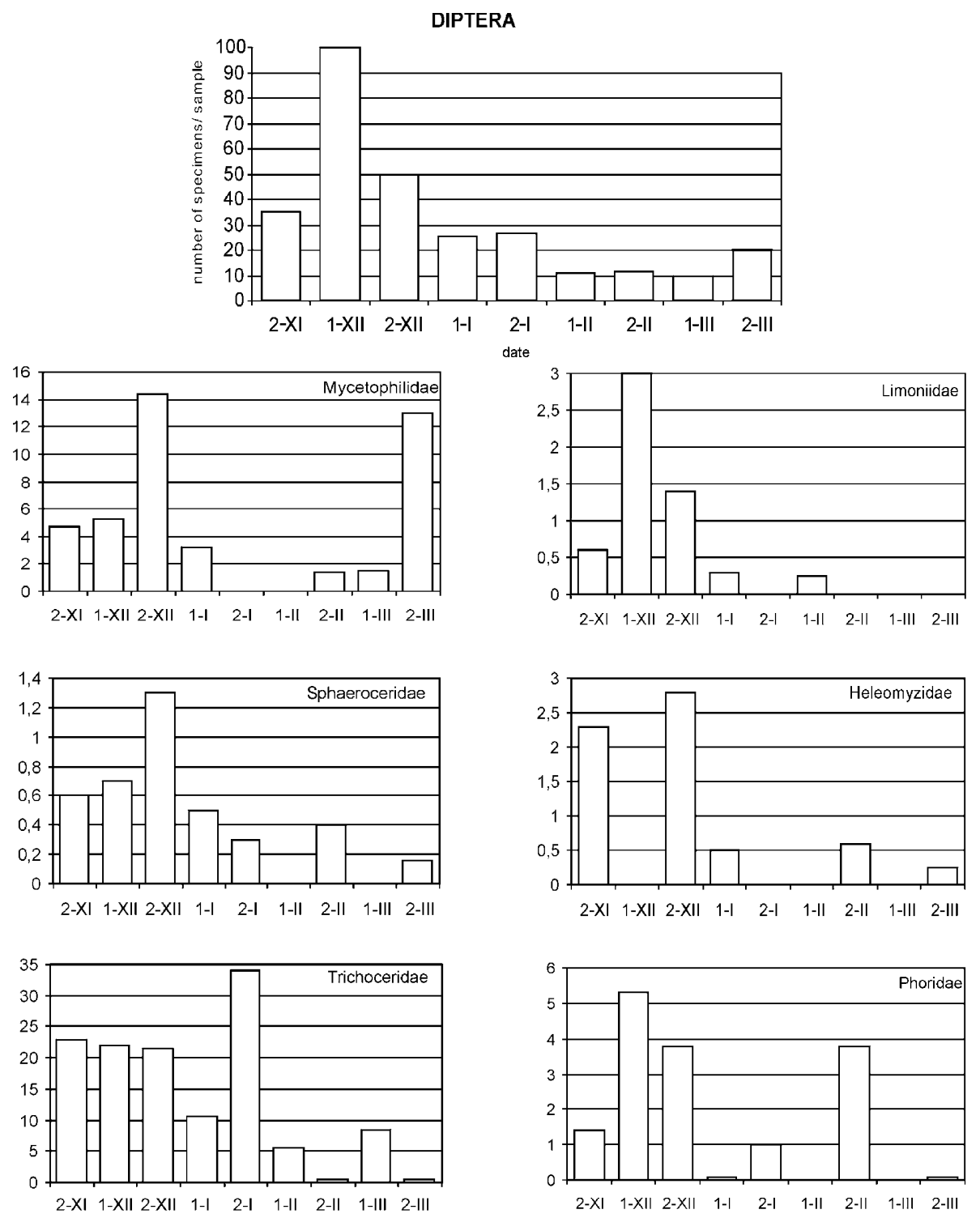

Fig. 5. Number of Diptera in total and of some families collected on snow from November to March in four winters, 1998-2002 (1-I - first part of January; 2-I - second part of January (2/I), etc.

insect groups were Coleoptera (12\%), Mecoptera (7\%) and Heteroptera $(6 \%)$. Of the other invertebrates $(11 \%)$, spiders predominated $(92 \%)$.

Eighty three species of Diptera were identified, belonging to the following 27 families: Agromyzidae, Anisopodidae, Anthomyiidae, Calliphoridae, Chironomidae, Chloropidae, Culicidae, Drosophilidae, Empididae, Ephydridae, Fannidae, Heleomyzidae, Lauxanidae, Limoniidae, Muscidae, Mycetophilidae, Opomyzidae, Phoridae, Sciaridae, Sciomyzidae, Sepsidae, Simuliidae, Sphaeroceridae, Syrphidae, Tephritidae, Tipulidae and Trichoceridae. Complete species lists will be publish elsewhere.

Most of the species belonged to the families Trichoceridae and Mycetophilidae, which made up 64\% of the material collected (Fig. 2). The families to which most of the species belonged were: Mycetophilidae (17 spp.), Trichoceridae (11 spp.) and Heleomyzidae (11 spp.). The next were the Phoridae (6 spp.), Sphaeroceridae (6 spp.) and Tephritidae (5 spp.) (Fig. 3).

Five species made up half of the material collected. From the Trichoceridae the species that were frequently collected were Trichocera (Saltrichocera) saltator (Harris, 1776) - 575 ind., T. (S.) implicata Dahl, 1967 196 ind. and T. (Trichocera) major Edwards, 1921 - 99 ind.; from the Mycetophilidae: Boletina gripha Dziedzicki, 1885 - 402 ind. and from the Phoridae Triphleba trinervis (Becker, 1901) - 190 ind. (Fig. 4).

The biggest catches of Diptera were in the first part of December (Fig. 5), and most belonged to the family Trichoceridae. The highest catches of Mycetophilidae, Limoniidae, Heleomyzidae, Sphaeroceridae and Phoridae were in December and of Trichoceridae in the second half of January. The small spring peak of Diptera collected in the second part of March consisted mainly of mycetophilids and drosophilids (not shown). 
DIPTERA
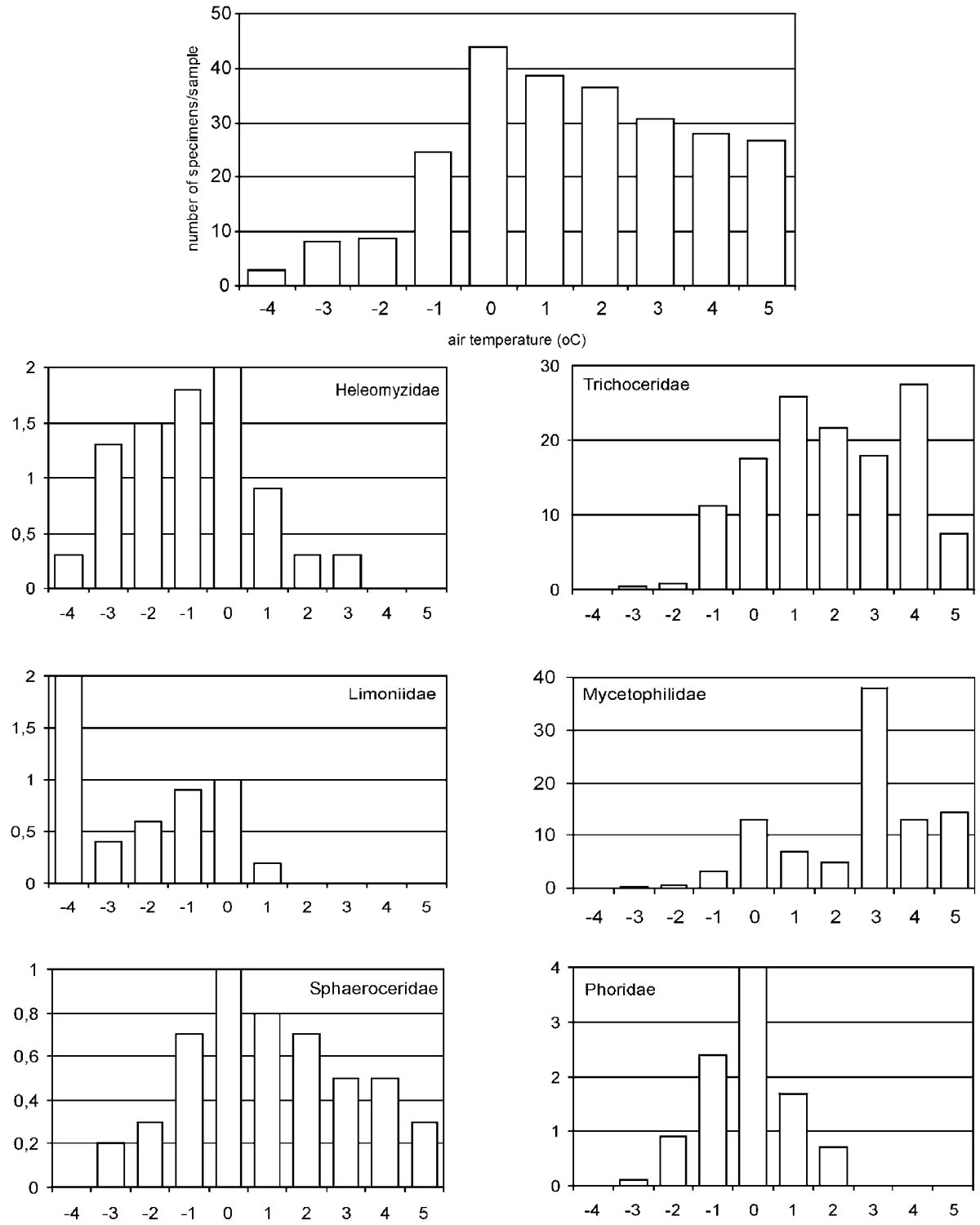

Fig. 6. Influence of temperature on the average number of Diptera (per sample) and that of some families collected on snow.

Flies were active on the snow when temperatures ranged from -4 to $+5^{\circ} \mathrm{C}$, with the peak when it was between -1 to $+5^{\circ} \mathrm{C}$ (Fig. 6). The most common species had peak activities only at slightly lower temperatures in case of Heleomyzidae and Limoniidae and at higher temperatures for the Trichoceridae and Mycetophilidae.

Flies occurred on the snow only when humidity reached more than $40 \%$, with the peak activity between 80 to $100 \%$ humidity (Fig. 7). Trichoceridae were only active when the humidity was close to $100 \%$ and Drosophilidae (not shown) and Heleomyzidae mostly at around 70-80\%.

Diptera occurred at all depths of snow cover, with greatest abundance when the snow was between 21 and $40 \mathrm{~cm}$ deep (Fig. 8). Limoniidae were the most frequently collected when it was 15 to $25 \mathrm{~cm}$ (not shown), Mycetophilidae when it was 5 to $25 \mathrm{~cm}$, Heleomyzidae 15 to $40 \mathrm{~cm}$ and Sphaeroceridae 10 to $25 \mathrm{~cm}$. The species of Phoridae were mainly associated with snow less than 10 $\mathrm{cm}$ deep and Drosophilidae mainly with $21-25 \mathrm{~cm}$ of snow. Only Trichoceridae occurred at all depths of snow cover.

\section{DISCUSSION}

Diptera were the most numerous and species-rich group of invertebrates collected on snow in this study. This is not surprising, as Diptera is one of the two greatest insect orders in Poland with more than 7 thousand species (Palaczyk et al., 2002) characterised by great internal heterogeneity, huge variety and very diverse biology. Flies live in all terrestrial habitats, including deserts and the Antarctica.

Of the 27 families, 9 were recorded on snow for the first time: Calliphoridae, Empididae, Fannidae, Opomyzidae, Sciaridae, Sepsidae, Simuliidae, Syrphidae, and Tipulidae. However, Drosophilidae, Empididae and Opomyzidae were previously recorded in traps during winter (Broen \& Mohrig, 1965), Sciaridae (Aitchison, 1979d) 

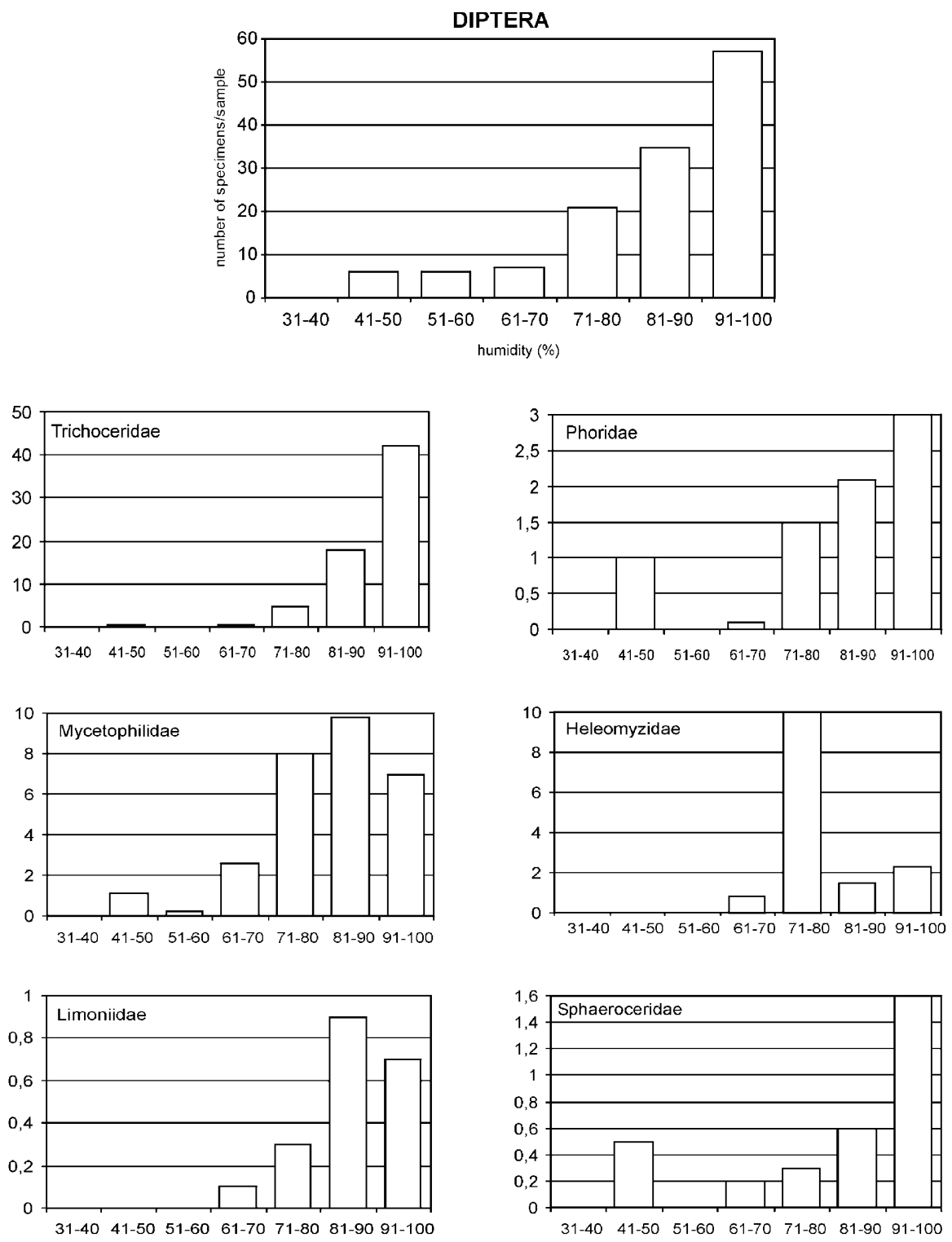

Fig. 7. Influence of humidity on the average number of Diptera and that of some families collected on snow.

and Muscidae (Łęgowski \& Łoziński, 1995) are active in the subnivean space. In the long-term study recorded here, the winter occurrence of Diastatidae (Broen \& Mohrig, 1965), Dolichopodidae (Frey, 1913) and Lonchopteridae (Tahvonen, 1942; Szulczewski, 1947) was not confirmed for Central Poland.

The results show that there is a rich ecological group of winter active flies on snow. Their occurrence is not accidental, but a regular winter phenomenon. It is, however, hard to discuss the results, as there are only a few, mostly rather outdated papers on the supranivean activity of Diptera. A detailed account of the individual species and families of Diptera recorded on the surface of snow in Norway is given by Hågvar \& Greve (2003), but only of the suborder Brachycera. Over a period of 20 years, they identified 15 families, among which Sphaeroceridae and Heleomyzidae predominated. This partly corresponds with the results from Central Poland, where the highest number of winter active species of Brachycera belong to the Heleomyzidae. The results from Finland (Frey, 1913) confirm the subdominant position of Mycetophilidae (9 spp.). Of the remaining 22 species from 10 families, presented in that paper, the greatest number belong to Sphaeroceridae (6 spp.) and Heleomyzidae (4 spp.), as in Norway (Hågvar \& Greve, 2003). According to Tahvonen (1942), who identified 18 species of winter Diptera from 6 families in Finland, the family with most species was Lonchopteridae. Szulczewski (1947) identified 20 species of snow-active flies from Central Poland, belonging to 7 families. In his study, the most diverse families were Sphaeroceridae (11 spp.), Trichoceridae (4 spp.) and Phoridae (3 spp.). Thus, certain families are typically winter active, but the ranking of the families may be locality dependent.

The most extensive studies on winter active Diptera in Germany are those by Broen \& Mohrig (1965) and Bährmann (1996), based on pitfall traps. Although the families recorded were the same, except for Lonchopteridae and 
DIPTERA
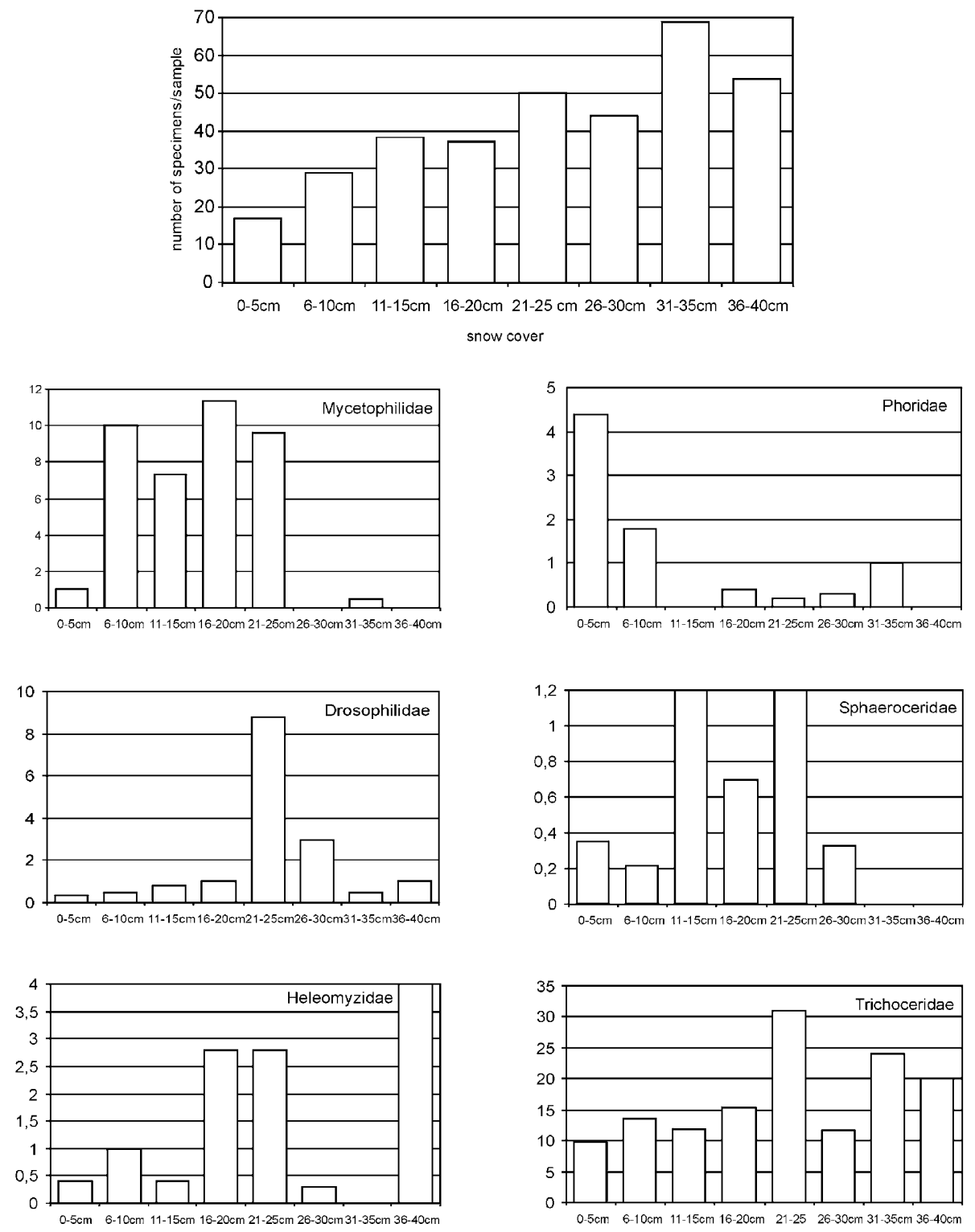

Fig. 8. Influence of snow depth on the average number of Diptera and that of some families collected on snow.

Diastatidae, their ranking differ from that in Central Poland. Broen \& Mohrig (1965) recorded 49 species of winter flies from 12 families, of which the Sphaeroceridae clearly predominate (11 species), and the Heleomyzidae (7 spp.), Ephydridae (7 spp.) and Lonchopteridae (6 spp.) are dominant. This corresponds with Hågvar \& Greve's results (in press), but differs from those of Aitchison (1979d). In Canada, she records Mycetophilidae (38\%) as the most numerous family in the subnivean space on a ridge between two ponds, Anthomyiidae $(49 \%)$ in a wood and Phoridae in a meadow. However, Bährmann (1996) records 16 families, of which the Sphaeroceridae, Phoridae and Heleomyzidae dominated.

Five species belonging to the three families made up half of the material in this study. The dominance of one of these species is recorded in the literature. Triphleba trinervis is the most numerous snow-active Phoridae spe- cies, not only in Poland (Soszyńska \& Durska, 2002) but also in Germany (Broen \& Mohrig, 1965). There it is recognized as the most numerous winter-active species of phorids and of Diptera. The dominance of 4 other species, Trichocera (S.) saltator, T. (S.) implicata, T. (T.) major and Boletina gripha was not recorded previously. There are close relationships between the climatic conditions and the occurrence of Diptera on the snow surface, which differenced among families.

\section{Phenology}

Trichoceridae, Mycetophilidae and Phoridae make up most of the early-winter activity peak of Diptera. At the end of December, Mycetophilidae, Sphaeroceridae and Heleomyzidae had their peak of activity (Fig. 5). In Germany the highest occurrence of winter-active flies is in the second part of December and in January, and is made up mainly of Trichoceridae, Phoridae and Sphaeroceridae 
(Broen \& Mohrig, 1965). Bährmann (1996) records that the winter activity of Brachycera is most intensive in November and December. Aitchison's (1979d) results for Canada differ from those for Poland and Germany. She found that the number and diversity of flies were greatest in October and steadily decreased from November onwards, most probably because of the much lower temperatures in Canadian, than Polish winters. Trichoceridae was the most frequent family recorded in winter in Central Poland, mostly from November to January. Dahl (1969) records that most species of Trichoceridae swarm in autumn and early-winter, and that it is a well known phenomenon. She revealed that $T$. saltator occurs from November to April, except for the turn of the year. The most numerous species in the mid-winter peak of activity of Mycetophilidae was Boletina gripha, the commonest species of mycetophilid. Plassmann (1989) also noted that B. gripha is the commonest species at the turn of the year. The spring peak in total Diptera in the second part of March was mainly due to species of Mycetophilidae, with some Sphaeroceridae and Heleomyzidae, and even Syrphidae. The highest number of species of Sphaeroceridae and Heleomyzidae was recorded from November to February, which conforms with Bährmann (1996) and Hågvar \& Greve's (2003) results. However, in the last study, many of the observations are for March and April, due to a very long period of snow-cover.

\section{Temperature}

In Trichoceridae and Mycetophilidae, the peak activity occurred between -1 to $5^{\circ} \mathrm{C}$. These results correspond to those of Dahl (1969), who mentions that Trichoceridae may be classified as cold-eurytherm, because of their poor tolerance of low temperature. Phoridae occurred mainly between -2 and $2^{\circ} \mathrm{C}$. According to Soszyńska \& Durska (2002) Phoridae occur in Central Poland at "medium winter temperatures", but in the mountains even down to $-4^{\circ} \mathrm{C}$. Generally, Heleomyzidae, Limoniidae Drosophilidae, Chloropidae, and to some extent Sphaeroceridae, occurred at lower temperatures, down to $-4^{\circ} \mathrm{C}$. Field observations and experiments of Sømme \& Östbye (1969) show that winter-active representatives of Heleomyzidae (Scoliocentra nigrinervis Wahlgr., which is active down to $-8^{\circ} \mathrm{C}$ and survives down to $-16^{\circ} \mathrm{C}$ ) and Limoniidae (Chionea araneoides Dalm.) have low supercooling points and can be active in a supercooled state. Wojtusiak (1950) also indicates that Ch. araneoides prefers lower temperatures than other winter-active species, and Hågvar (1971) reports that it is active at $-6^{\circ} \mathrm{C}$. Hågvar \& Greve (2003) conclude that species of Heleomyzidae are well adapted to winter activity. The dominant sphaerocerid species in their study, Crumomyia notabilis, is also recognized as extremely cold-tolerant and psychrophilic (Roháček, 1991).

\section{Humidity}

Generally, the occurrence of Diptera during winter is strongly associated with high humidity, mainly above $70 \%$ (Fig. 7). In comparison, that of Coleoptera is highest when humidity ranges from 60 to $70 \%$ (Soszyńska, unpubl.). There are differences among the families of Diptera. Flies of the suborder Nematocera preferred the highest humidities, with the Trichoceridae preferring almost $100 \%$. This agrees with the findings of Dahl (1969), who revealed that weakly sclerotized Nematocera are especially vulnerable to desiccation and prefer highly humid habitats. The tolerance of low temperatures species of Trichoceridae was not very great, as already mentioned. Dahl (1969) records that high humidity extends survival at temperatures down to $-5^{\circ} \mathrm{C}$. In contrast, other families, Heleomyzidae, Sphaeroceridae and Drosophilidae (subordo Brachycera), are not so sensitive to desiccation and occurred at lower humidities.

\section{Snow thickness}

The depth of snow also affected the species composition of the snow surface fauna. Flies occurred most frequently when the depth of the snow was 20 to $40 \mathrm{~cm}$. It is known that snow insulates the subnivean space from the fluctuations in air temperature, and that flies remain active during the period of snow-cover and reach the snow surface via tree stems etc. Only the occurrence of the family Trichoceridae was independent of snow depth, probably because they seek shelter from unfavourable weather conditions not only in the subnivean space but under tree bark (pers. observ.). Supranivean activity of Phoridae was strongly associated with thin layers of snow. Perhaps their large size and relatively long wings makes it difficult for them to penetrate the snow layer. This conforms with the observations of Soszyńska \& Durska (2002) that the wings of snow-active specimens of Triphleba trinervis (Phoridae) are ragged, probably a result of penetrating the snow cover and directly reduce the body size.

\section{Ecological remarks}

Clearly, there is a species-rich ecological group of winter active flies. They often show a deviating phenology, physiology and habitat choice (Hågvar \& Greve, in press) and have physiological, behavioural and morphological adaptations for surviving on snow. Hågvar \& Greve (in press) also show that Diptera occur on snow mainly in overcast weather, which is often connected with high humidity and a stable temperature. They point out that such stable and predictable conditions would give the flies sufficient time to reach the subnivean space or other microhabitats, if the temperature started to fall. Both Bährmann (1996) and Hågvar \& Greve (2003) stress that many winter active Brachycera are saprophagous as larvae. Hågvar \& Greve (2003) suggest that cold-adapted, saprophagous flies would be at an advantage over other insects in spring when colonizing the excrement and carrion that accumulated during winter. It is also pointed out that winter active species avoid competition, predation (Aitchison, 2001) and parasitization (Durska, 2003). Furthermore, the snow surface may simplify partner finding, copulation and migration (Soszyńska \& Durska, 2002). In the light of the close relationship between snow cover and the winter activity of several insects, a warming of global climate may affect this fauna. 
ACKNOWLEDGEMENTS. I thank especially A. Palaczyk from the Institute of Systematics and Evolution of Animals, Polish Academy of Science in Kraków, for his help with the identification of some families of Diptera. I am grateful to J. Poteraj for correcting the English of a previous version of the manuscript and anonymous referees for their critical reading of the manuscript. This work was supported by a grant from State Committee for Scientific Research (KBN), grant nr 6 PO4F 060 19.

\section{REFERENCES}

Aitchison C.W. 1978a: Notes on low temperature and winter activity of Homoptera in Manitoba. Manitoba Entomol. 12: $58-60$.

Aitchison C.W. 1978b: Spiders active under snow in southern Canada. Symp. Zool. Soc. Lond. 42: 139-148.

Aitchison C.W. 1979a: Winter-active subnivean invertebrates in southern Canada. I. Collembola. Pedobiologia 19: 113-120.

Aitchison C.W. 1979b: Winter-active subnivean invertebrates in southern Canada. II. Coleoptera. Pedobiologia 19: 121-128.

Aitchison C.W. 1979c: Winter-active subnivean invertebrates in southern Canada. III. Acari. Pedobiologia 19: 153-160.

Aitchison C.W. 1979d: Winter-active subnivean invertebrates in Southern Canada. IV. Diptera and Hymenoptera. Pedobiologia 19: 176-182.

Aitchison C.W. 1979e: Notes on low temperature activity of oligochaetes, gastropods and centripedes in southern Canada. Am. Midl. Nat. 102: 399-400.

Aitchison C.W. 1979f: Low temperature activity of pseudoscorpions and phalangids in southern Manitoba. J. Arachnol. 7: $85-86$.

Aitchison C.W. 1983: Low temperature and preferred feeding by winter-active Collembola (Insecta, Apterygota). Pedobiologia 25: 27-36.

Aitchison C.W. 2001: The effect of snow cover on small animals. In Jones H.G., Pomeroy J.W., Walker D.A. \& Hohem R.W. (eds): Snow Ecology. Cambridge University Press, pp. 229-265.

Ashmole N.P., Nelson J.M., Shaw M.R. \& Garside A. 1983: Insects and spiders on snowfield in the Cairngorms, Scotland. J. Nat. Hist. 17: 599-613.

BÄHRMANN R. 1996: Winteraktive Zweiflügler (Insecta, Diptera Brachycera) in Xerothermrasen Thüringens. Studia Dipterol. 3: $259-274$.

BıESZYŃSKI S. 1960: Lepidoptera - Geometridae. Keys to the Identification of Polish Insects. 27(46a). PWN, Warszawa, 149 pp. (in Polish).

Broen B. \& Mohrig W. 1965: Zur Frage der Winteraktivität von Dipteren in der Bodenstreu. Dt. Entomol. Z. (N.F.) 12(4/5): 303-310.

Brummer-Korvenkontio M. \& Brummer-Korvenkontio L. 1980: Springtails (Collembola) on and in snow. Mem. Soc. F. Fl. Fenn. 56: 91-94.

BucK M. 1997: Untersuchungen zur ökologischen Einnischung saprophager Dipteren unter besonderer Berücksichtigung der Phoridae und Sphaeroceridae (Brachycera/Cyclorrhapha). $\mathrm{PhD}$. Thesis, Universität Ulm, Germany.

Courtin G.M., Shourtouse J.D. \& West R.J. 1984: Energy relations of the snow scorpionfly Boreus brumalis (Mecoptera) on the surface of the snow. Oikos 43: 241-245.

DAHL C. 1969: The influence of light, humidity and temperature on Trichoceridae (Diptera). Oikos 20: 409-430.

DurSKA E. 2003: The phenology of Triphleba Rondani species (Diptera: Phoridae) in moist pine forests in the Białowieża Forest. Entomol. Fenn. 14: 177-182.
FREY R. 1913: Beitrag zur Kenntnis der Arthropoden-Fauna im Winter. Mem. Soc. F. Fl. Fenn. 39: 106-121.

HÅGVAR S. 1971: Field observations on the ecology of snow insects, Chionea araneoides Dalm. (Dipt., Tipulidae). Norsk Entomol. Tiddskr. 18: 33-37.

HÅGVAR S. 1976: Phenology of egg devolopment and egg-laying in a winter-active insect, Chionea araneoides Dalm. (Dipt., Tipulidae). Norw. J. Entomol. 23: 193-195.

HÅGVAR S. 2000: Navigation and behaviour of four Collembola species migrating on the snow surface. Pedobiologia 44: 221-233.

HÅGVAR S. 2001: Occurrence and migration on snow, and phenology of egg-laying in the winter-active insects Boreus sp. (Mecoptera). Norw. J. Entomol. 48: 51-60.

HÅgVAR S. \& Greve L. 2003: Winter active flies (Diptera, Brachycera) recorded on snow - a long-term study in south Norway. Stud. Dipter. 10: 401-421.

HÅgVAR S. \& OstBye E. 1973: Notes on some winter-active Chironomidae. Norsk Entomol. Tiddskr. 20: 253-257.

HANCOCK E.G. 1991: Winter activity in the Common Window Gnat, Sylvicola cinctus (Fabr.) (Diptera, Anisopodidae). Dipt. Digest 8: 18-22.

HuHTA V. \& Viramo J. 1979: Spiders active on snow in northern Finland. Ann. Zool. Fenn. 16: 169-176.

JONSSON B. \& SANDLUND O.T. 1975: Notes on winter activity of two Diamesa species (Dipt., Chironomidae) from Voss, Norway. Norw. J. Entomol. 22: 1-6.

KŁYsIK K. 2001: Climate. In Liszewski S. (ed.): Monograph of Łódź Province. Łódzkie Towarzystwo Naukowe, Łódź, pp. 68-81 (in Polish).

KJERANDSEN J. 1993: Diptera in mines and other cave systems in southern Norway. Entomol. Fenn. 4: 151-160.

Kondracki J. 2000: Regional Geography of Poland. PWN, Warszawa, 442 pp. (in Polish).

Koponen S. 1989: Spiders (Araneaa) on snow surface in subarctic Lapland. Aquilo (Zool.) 24: 91-94.

KrZemiński W. 1978: The genera Chionea Dalm. and Niphadobata Enderl. (Diptera, Limoniidae) in Poland. Zesz. Nauk. Uniw. Jagiellonsk. (Zool.) 24: 109-127.

KurowsKi J.K. (eds) 1998: Wzniesienia Lódzkie Landscape Park. Eko-Wynik, Łódź, 183 pp. (in Polish).

ŁĘGOWSKI D. \& ŁozIŃSKI J. 1995: A contribution to the study of spiders and epigeic insects present in five forest ranges during winter and early spring. Ann. Warsaw Agricult. Univ. 46: 31-39.

Marchand W. 1917: Notes on the habits of the snow-fly (Chionea). Psyche 11: 142-152.

NÄSMARK O. 1964: Subnival winter activity in terrest evertebrates. Zool. Revy 26: 5-15 (in Swedish, English abstr.).

Palaczyk A., Soszyński B., Klasa A., Bystrowski C., MikotAJCZYK W. \& KrZemińsKI W. 2002: Diptera flies. In Red List of Threatened Animals in Poland. PAN IOP, Kraków, pp. 38-44 (in Polish, English abstr.).

Plassmann E. 1975: Zum Vorkommen imaginal Pilzmücken (Diptera: Mycetophilidae) in Bodenfallen während der Wintermonate im Messauregebiet. Entomol. Tiddskr. 96: 27-28.

Plassmann E. 1989: Winteraktivität von adulten Pilzmücken eines Birkenbestandes des östlichen schleswigholsteinischen Hügellandes (Diptera, Nematocera, Mycetophilidae). Z. Entomol. 10(16): 257-272.

RENKEN W. 1956: Untersuchungen über Winterlager der Insekten. Z. Morphol. Ökol. Tiere 45: 34-106.

RонÁČ́EK J. 1991: Sphaeroceridae (Diptera) of Czechoslovakaia. Part 2. Crumomyia Macquart. Čas. Slez. Muz. Opava (A) 40: $1-27$. 
Shorthouse J.D. 1979: Observations on the snow scorpionfly Boreus brumalis Fitch (Boreidae: Mecoptera) in Sudbury, Ontario. Quest. Entomol. 15: 341-344.

SoszyŃSKA A. \& Durska E. 2002: Cold-adapted scuttle-flies species of Triphleba Rondani (Diptera: Phoridae). Ann. Zool. 52: 279-283.

Sowa R. \& SzcZęsny B. 1970: Stoneflies (Plecoptera) and caddisflies (Trichoptera) in the area of Babia Góra. Ochr. Przyr. 35: 221-268 (in Polish).

Sømme L. \& Östbye E. 1969: Cold-hardiness in some winter active insects. Norsk Entomol. Tidsskr. 16: 45-48.

Starmach K., Wróbel S. \& Pasternak K. 1976: Hydrobiology. Limnology. PWN, Warszawa, 621 pp. (in Polish).

StRÜBING H. 1958: Schnee-Insekten. Die neue Brehm-Bücherei, Wittenberg, Lutherstadt, Berlin, 47 pp.
SZCZESNY B. 1968: New and rare species of caddisflies (Trichoptera) in the fauna of Poland. Acta Hydrobiol. 8: 341-346.

Szulczewski J. 1947: Snow Fauna of Wielkopolski National Park. Prace Monogr. WPN, Poznańskie Towarzystwo Przyjaciół Nauki, Poznań, 18 pp. (in Polish).

TAhVonen E. 1942: Beobachtungen über Winterinsekten. Ann. Entomol. Fenn. 8: 203-214.

VANĚK J. 1973: Mass emergence of species Thaumatomyia notata Meig. (Diptera, Chloropidae) in Karkonosze Mountain. Opera Corcont. 10: 272-273 (in Czech).

VIRAMO J. 1989: Boreus (Insecta, Mecoptera) active on snow in northern Finland. Aquilo (Zool.) 24: 71-75.

WoJTUSIAK H. 1950: The temperature preferendum of winter insects of the genus Boreus (Panorpata) and Chionea (Diptera). Bull. Ac. Pol. Sci. (B) 11: 125-143.

Received August 22, 2003; revised March 30, 2004; accepted June 23, 2004 